\title{
Occupational Stress among Pandyan Grama Bank Employees in Virudhunagar District, Tamil Nadu, India.
}

\author{
R. Sam Renu ${ }^{1}$, G. Arumugasamy ${ }^{2}$ \\ ${ }^{I}$ (Assistant Professor in Management Studies, Ponjesly College of Engineering, Nagercoil, India) \\ ${ }^{2}$ (Associate Professor \& HOD in Management Studies, Ponjesly College of Engineering, Nagercoil, India)
}

\begin{abstract}
The study aimed to investigate the occupational stress among pandyan grama bank employees in Virudhunager District. The sample for the study consisted of 165 of the respondents. While 10 fell under senior manager III grade, 35 came under senior manager II grade, 90 were of officer I grade and the remaining 30 fell under the clerical grade. The study objectives are to measure the level of stress among the employees of Pandyan Grama Bank in Virudhunager District, to analyze the causal factors of stress among the employees, to study the consequences of stress of employees. The following statistical tools are used for the analysis of research data. Percentage analysis, Chi-square test, Rank order rating scale, Garett Ranking Method, Mean Score Analysis-Likert 5 point scale and ANOVA. The research design chosen is descriptive as the study reveals the existing facts. Descriptive research is the study which describes the characteristics of a particular individual or a group. The present study reveals that stress in work setting stems from different sources such as individuals, group, organizational, and environmental. Though the precise impact of stress is difficult to predict, it adversely affects the physiological, psychological and behavioural aspects of employees experiencing to it. Effects of stress vary from employee to employee depending on their resilience capacity, perception of stimuli, prior experience to it, and complexity of task to be performed. The study suggests that stress can be managed at both the individual level and the organizational level. Individual approaches to manage stress include exercise, behavioral control, proper diet, meditation, relaxation and the like.
\end{abstract}

Keywords - Occupational Stress, Corporate Profits, Emotional, Behaviour.

\section{INTRODUCTION}

The origin of the concept of stress predates antiquity. Derived from the Latin word "Stringere" Stress was popularly used in the seventeenth century to means hardship, strain, adversity, or affliction. It was used in the eighteenth and nineteenth centuries to denote force, pressure, strain, or strong efforts with reference to an object or person. In the modern times, stress has become a buzz word and legitimate concern for people of all walks of life. In fact, no one is immune to stress. Right from the time of birth till death, an individual is invariably exposed to various stressful situations. Hence stress is a subject, which is hard to avoid; stress is a much and widely talked about phenomenon in corporate (western) world because it is a costly business expense that affects both employee health and corporate profits.

Stress has existed throughout the evolution, about 4 billion years ago, violent collision of rock and ice along with dust and gas, led to the formation of a new planet. The planet survives more than 100 million years of meltdown to give birth to microscopic life. These first organisms endured the harshest of conditions - lack of oxygen, exposure to sun's UV rays and other inhospitable elements, to hang on to their dear life. Roughly 300,000 years ago, the Neanderthals learnt to use fire in a controlled way, to survive the Glacial Age. And around 30,000 years, Homosapiens with their dominant gene constitutions and better coping skills, won the game of survival. Each step of evolution a test of survival, and survival, a matter of coping with the stress of changing conditions.

Stress at work resulting from increasing complexities of work and its divergent demand, has become a prominent and pervading feature of the modern organizations. Caplan Cobb and French (1975) have accordingly defined occupational stress as "any characteristics of job environment which poses a threat to the individual". Copper and Marshall (1976) have expressed that "by occupational stress is meant negative environmental factors or stressors associated with a particular job". Maslach and Jackson (1982) view "work pressure as one of the determinants of burnout". Friesen and Sarrors (1989) have found "that only one burnout dimension, i.e. emotional exhaustion, was closely related to work stress". Occupational stress may produce both overt psychological and physiologic disabilities. However, it may also cause subtle manifestation of morbidity that can affect personal well being and productivity (Quick, Murphy, Harel and Romen 1992). 


\subsection{Origin of the Study Area}

Pandyan Grama Bank a scheduled bank is in the public sector in India under Regional Rural Banks Act, 1976. It was established on $9^{\text {th }}$ March, 1977 with its Head Office at Sattur, a semi-urban centre in Virudhunagar district in Tamilnadu. It is sponsored by Indian Overseas Bank and has been catering mainly to the needs of the rural clientele. The primary objective of the bank is to finance farm sector and other employment generation programmes. The head office of the Bank was shifted to Virudhunagar, the District Head Quarters on $16^{\text {th }}$ July, 1993 and was functioning in a rental building up to $30^{\text {th }}$ December, 2000. From $31^{\text {st }}$ October, 2000 onwards, the Head office has started functioning in its own building. The Bank is operating in fifteen districts, namely, Virudhunagar, Sivagangai, Ramanathapuram, Thirunelveli, Thoothukudi, Pudukottai, Madurai, Dindugal, Kanyakumari, Theni, Thiruchirappalli, Thanjavur, Perambalur and Nagapattinam.

\subsection{Statement of the Problem}

Pandyan Grama Bank is one of the scheduled banks in the public sector in India, established under the Regional Rural Banks Act, 1976. There are 935 employees working in all the branches of Regional Rural Bank; of them 165 employees are working in Pandyan Grama Bank in Virudhunagar District.

\subsection{Objectives of the Study}

* To measure the level of stress among the employees of Pandyan Grama Bank in Virudhunager District.

* To analyse the causal factors of stress among the employees.

* To study the consequences of stress of employees.

* To offer suitable suggestions to cope with the stress of the employees.

\subsection{Scope for the Study}

The study attempts to analyse the level of occupational stress of Pandyan Grama bank employees in Virudhunagar District. The present study takes a close look at the stress related issues facing the employees working Pandyan Grama bank and analyse the factors responsible for the same and suggest suitable measures to tackle the problem of the occupational stress.

\subsection{Sources of Data}

\section{METHODOLOGY}

The present study depended on both secondary and primary data. The secondary data were collected from the standard text books, leading journal, magazines, reports and records and relevant websites relating to the topic chosen for the study.

\subsection{Questionnaire}

The required primary data were collected by administering interview schedules to the respondents. The questioner was pre-tested before issuing it to the respondents.

\subsection{Census Study}

The total number of employees working in Pandyan Grama Bank in Virudhunagar District as on $1^{\text {st }}$ April 2009 was 165 . Owing to the limited number of employees, it is thought fit to contact all the 165 employees of the Bank. Hence, there was a census study of Bank employees, to find out their level of work stress.

\subsection{Statistical Tools}

The following statistical tools are used for the analysis of research data.

1. Percentage Analysis

2. Chi-square test

3. Rank order rating scale

4. Garett Ranking Method

5. Mean Score Analysis- Likert 5 point scale and ANOVA (One way)

\subsection{Research Design}

The research design chosen is descriptive as the study reveals the existing facts. Descriptive research is the study which describes the characteristics of a particular individual or a group. This study is about selected variables of stress. Thus the design of the present study is descriptive design of conclusive one. 
Occupational Stress among Pandyan Grama Bank Employees in Virudhunagar District, India.

\subsection{Sample size}

Table-1 shows the sample size of the respondents. While 10 fell under Senior Manager III grade, 35 came under Senior Manager II grade, 90 were of Officer I grade and the remaining 30 fell under the clerical grade.

Table-1

Sample Size

\begin{tabular}{|c|c|c|}
\hline Sl. No. & Particulars & Number of Employees \\
\hline 1 & Senior Manager - III & 10 \\
\hline 2 & Senior Manager - II & 35 \\
\hline 3 & Officer - I & 90 \\
\hline 4 & Clerk & 30 \\
\hline & Total & 165 \\
\hline
\end{tabular}

Source: Primary Data

\section{ANALYSIS OF DATA}

The Managing Occupational Stress among Employees in Pandyan Grama Bank shown in Table - No.2.

Table-2

Managing Occupational Stress

\begin{tabular}{|c|l|c|c|}
\hline Sl. No. & \multicolumn{1}{|c|}{ Particulars } & Frequency & Total \% \\
\hline $\mathbf{1}$ & $\begin{array}{l}\text { Taking steps to control my physical and emotional } \\
\text { well being }\end{array}$ & 38 & 23 \\
\hline $\mathbf{2}$ & $\begin{array}{l}\text { Avoiding pitfalls by identifying knee jerk habits and } \\
\text { negative attitude that add to my work stress }\end{array}$ & 19 & 21.5 \\
\hline $\mathbf{3}$ & $\begin{array}{l}\text { Learning better communication skills to ease and } \\
\text { improve my relationships with management and co- } \\
\text { workers }\end{array}$ & 45 & 22 \\
\hline $\mathbf{4}$ & $\begin{array}{l}\text { Try to come earlier in the morning from home to } \\
\text { working organization }\end{array}$ & 34 & 13.3 \\
\hline $\mathbf{5}$ & Create a balanced schedule & 7 & 20.6 \\
\hline $\mathbf{6}$ & Plan to regular breaks in work & $\mathbf{1 6 5}$ & 4.3 \\
\hline & \multicolumn{1}{|c|}{ Total } & $\mathbf{1 0 0}$ \\
\hline
\end{tabular}

\section{Source: Primary Data.}

It is evident that a sizable number of $27.3 \%$ began to "learn better communication skills to ease and improve their relationships with management and co-workers for managing occupational stress. Also, the above analysis evidences that the employees resort to one form of action or another to manage their work stress. Figure-1 portrays this phenomenon.

Figure - 1

Managing Occupational Stress

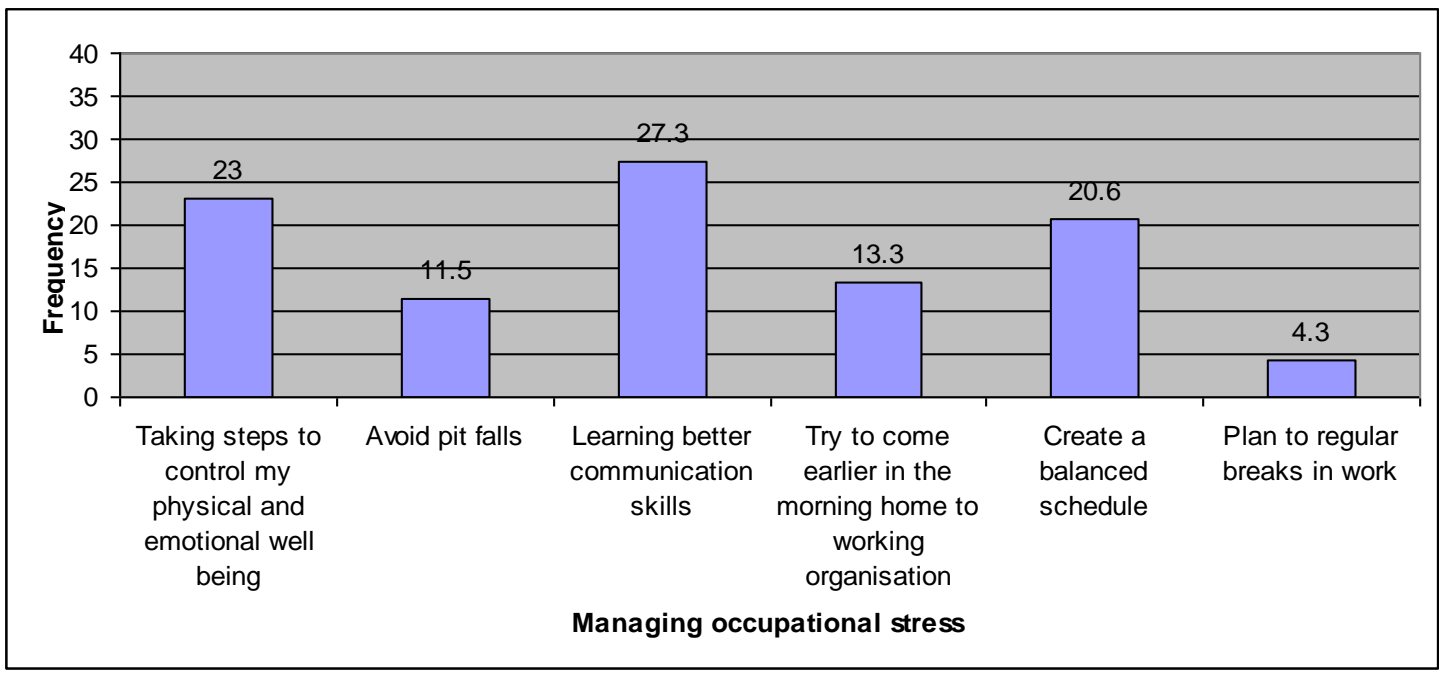


Occupational Stress among Pandyan Grama Bank Employees in Virudhunagar District, India.

\section{FINDINGS OF THE STUDY}

The main findings recorded in the preceding chapters of the present research report are consolidated and given in the following passages.

\subsection{Demographic Factor}

* It was found that a sizable number of 33.3\% of respondents were in the age grouping of 40-49 years.

* A majority of $84.2 \%$ respondents were males.

* Most of $84.8 \%$ of respondents were married.

- Majority of 54.5\% respondents were graduates.

* Most of $69.7 \%$ of respondents had nuclear families.

* A majority of $54.5 \%$ of respondents were Officer I scale.

* A sizable number of $47.3 \%$ of respondents had the monthly salary of Rs. 20,000 and above.

- A majority of $56.4 \%$ of respondents were residing in urban area.

\subsection{Level of Stress}

* It was a revelation that $31.5 \%$ of respondents 'Often' experienced the feeling of stress.

* A considerable number of respondents of $47.9 \%$ had 26 to $50 \%$ level of stress, namely, normal level of stress.

\subsection{Causes of Stress}

* A majority of $56.4 \%$ of the respondents were getting stress due to 'Work Load'

* To a sizable number of $29.7 \%$ respondents, the source of stress was their supervisors.

* Most of $64.2 \%$ of respondents committed wrong in their work; and, $65 \%$ of them had experience of 'lesser concentration in work' due to their wrong doing of work

* A majority of $54.5 \%$ of respondents, as their reaction, 'avoided to meet the person concerned' who was responsible for the occurrence of stress.

\subsection{Subordinates' view of Stressor}

* It is heartening that a vast majority of $92.7 \%$ respondents have accepted the superiors' suggestions and ideas.

* A vast majority of $88 \%$ of respondents' feeling were 'Indirectly' hurt by their superiors'.

* A majority of $51.9 \%$ were 'Scolded' by their superiors.

* The feelings of respondents, namely, $45.5 \%$ were 'Indirectly' hurt by their superior by way of 'dumping heavy work'

* A vast majority of nearly $90 \%$ of respondents expressed that on the whole their relationship with their superiors is either good or satisfactory.

\subsection{Superiors' view of concerning Stress}

* A majority of $58.8 \%$ of superiors, while they were at stress, have not met their subordinates.

- Superiors of $54.4 \%$ while they were at stress had reaction in the form of 'tension' at the time of meeting the subordinates.

\subsection{Co-workers as a source of Stress}

* Majority of $65.5 \%$ respondents have experienced stress feeling from the action of co-employees.

- Respondents of $38.9 \%$ cited the reason of 'lack of co-operation from co-employees as the source of their stress.

\subsection{Dealing with Bank Customers}

- A majority of $52.1 \%$ respondents may also turn out to be a stressor. It is a revelation that while $46.5 \%$ experienced stress feeling quite often, $44.2 \%$ experienced such feeling. Either rarely or sometimes in dealings with the customers. The remaining $9.3 \%$ never experienced such a feeling.

\subsection{Management policy as a source of Work Stress}

* It was a revelation that a majority of $60.6 \%$ of respondents considered that the policies of management changed frequently.

* A sizable number of $30 \%$ of respondents were 'frequently' affected by changes in management policies. 


\subsection{Organizational factors as a source of Work Stress}

* A majority of $83.6 \%$ respondents cope with their organizational rigid rules; and, $30.4 \%$ of respondents 'always' cope with their organizational rigid rules.

* A sizable number of $31.5 \%$ of respondents reported that their higher authorities 'often' care for their self respect.

- A vast majority of nearly $87 \%$ of respondents were satisfied with their organizational working environment.

* Most of 65\% of respondents were satisfied with their organizational welfare measures.

- A significant finding is that 'ineffective communication' is the most important organizational factor of job stress among employees $(41.73 \%)$.

\subsection{Personal factors as the source of work Stress}

* A majority of nearly $60 \%$ of respondents had opportunity 'frequently' for independent thought and actions in their job.

* A majority of 59.4\% of respondents had provision to take occasional break in the job; and, nearly $70 \%$ of respondents 'frequently' took occasional break in the job.

* A sizable number of $27.3 \%$ respondents had 'financial problem' as a source of personal factor caused stress.

* It was found that 'heavy work load' is a reason as a source of work stress among bank employees.

\subsection{Psychological factors as the source of Stress}

* A vast majority of $80.6 \%$ respondents felt psychological factor as the source of work stress.

* Respondents namely, $32.47 \%$ ' reported 'emotional out burst' suffered from due to the psychological factor as a source of work stress.

* A vast majority of $63.7 \%$ respondents had 'longtime' stress.

* A majority of $52.1 \%$ of respondents had 'heavy' work load in their job.

* A majority of $62.4 \%$ respondents had excessive job responsibilities; and, $83.5 \%$ experienced hardship due to excessive job responsibilities.

* A large number of $47.7 \%$ respondents had 'insufficient time to spend with their family members and friends' because of having excessive job responsibilities.

* A majority of $63.7 \%$ of respondents had chronic stress.

* A sizable number of $39.1 \%$ of respondents mitigated the pressure of the chronic stress by meeting and conversing with their 'friends'

\section{CONCLUSION}

Shakespeare, in his drama 'King Lear' aptly remarks that it is the actions of the mankind that are responsible for the fruits they reap. Danial Goleman says, if the actions of leaders are to be functional, they should have a critical mass of emotional intelligence.

The present study was conducted to examine the Occupational stress among employees in Pandyan Grama Bank, Virudhunagar District". Stress is inevitable in human life. Stress is non-specific response to demands from organization environment that results in physical, psychological, and behavioural deviations for bank employees'. No one is immune to stress. The present study reveals that stress in work setting stems from different sources such as individuals, group, organizational, and environmental. Though the precise impact of stress is difficult to predict, it adversely affects the physiological, psychological and behavioural aspects of employees experiencing to it. Effects of stress vary from employee to employee depending on their resilience capacity, perception of stimuli, prior experience to it, and complexity of task to be performed. The study suggests that stress can be managed at both the individual level and the organizational level. Individual approaches to manage stress include exercise, behavioral control, proper diet, meditation, relaxation and the like.

The study also pinpoints organizational strategies to manage stress which include clarity of employee roles, procedures, policies and rules, change in organizational structure, counseling, spread of message of evil effects of stress and so forth.

"Prevention is better than cure" 


\section{Books:}

\section{REFERENCES}

[1] Khanka S.S, Organisational Behaviour, S. Chand and company Limited, First Edition, 2000.

[2] Mirza S. Saiyadain, Organisational Behaviour, Tata Mc Graw-Hill publishing company Limited, New Delhi, 2004.

[3] Srivastava A.K, Management of occupational stress( Theories and practice) Gyan publishing house, New Delhi, 1999.

[4] Dr. Umesh Sharma, Stress management (through ancient wisdom and modern science), First Edition, New Delhi, 2005.

[5] Uma Sekaran, Organisational behavior, Tata Mc Graw-Hill publishing company Limited, New Delhi, Second Edition, 2005.

\section{Journals:}

[1] Dr. Bob Murray, Building high performance team, managing a high performance team in stressful times, the journal of Effective Executive, Vol-XII, No.5, May 2009.

[2] Debdatta Gupta, Mergers and Acquisitions, Stress among BPO employees, Vol-VIII, Issue-VIII, August 2008.

[3] Daisy Chauhan, Effect of job involvement on burnout, The Indian journal of Industrial Relations, Vol-44, No.3, January 2009.

[4] Kavitha Singh, A review of economic and social development, Emotional Intelligence and workplace effectiveness, The Indian journal of Industrial Relations, Vol-44, N0.2, Oct-2009.

[5] Kakolisen, A review of economic and social development relationship between job satisfaction and job stress amongst teachers and managers, The Indian jounal of Industrial Relations, Vol-44, No.1, July 2008.

[6] Kathirvel .N , A study on stress among employees working in BPOs with special reference to Coimbatore, The IUP journal of management research, Vol-VIII, No.11, 2009.

[7] Prof. Krishnan Nair.N, Stress among Bank employees in India, The journal of management research, Vol-I, Issue-I, July2008.

[8] Lakshmi Ravikanth, Paraxis, Wired for stress, Business line's journal of management, Vol-3, Issue-2, May 2001.

[9] Parul Rishi, Women in Mnagaement, I love my stress, Jouranl of Effective Executive, Vol-VII, No.9, Oct - 2007.

[10] Vasumathy .S and Catrherine Joseph, Mergers and Acquistions, Emotional Intelligence, The journal of HRM review, Vol-VIII, Issue-VIII, August 2008.

\section{Reports and Records:}

Annual Report of Pandyan Grama Bank.

\section{Websites:}

[1] www.about.com

[2] www.changingminds.org/explanations/stress/stress_causes.htm

[3] www.ehealthmd.com

[4] www.mindpowerindia.com/mindnachine-lab/stress-buster.htm

[5] www.stressfocus.com

[6] www.stressfocus.com/stress-focus-article/post-traumaticstress.htm 